\title{
A Mini Review on Current Status of Aquaculture Sector in Turkey
}

\section{Bozkurt Y*}

Faculty of Marine Sciences and Technology, Iskenderun Technical University, Turkey

*Corresponding author: Yusuf Bozkurt, Faculty of Marine Sciences and Technology, Iskenderun Technical University, Hatay, Turkey, Tel: 351966870 405; Email: yfbozkurt@hotmail.com

\section{Mini Review \\ Volume 3 Issue 4}

Received Date: October 09, 2019

Published Date: December 27, 2019

DOI: $10.23880 /$ ijoac- 16000175

\section{Abstract}

Aquaculture is an essential sector providing a considerable portion of the food requirement of the world. Also, aquaculture has been determined as the fastest growing food sector of the world by FAO. Aquatic products obtained by the way of hunting from the seas is limited. Thus, proportion of these products obtaining via aquaculture have been increasing. In accordance with this situation, aquaculture is a rapidly developing sector in Turkey as in the whole world. From this point of view, with the necessary investments and foundation of the friendly environment systems, aquaculture is getting popular in Turkey.

Keywords: Sectors; Turkey; FAO

\section{Introduction}

Turkey is a peninsula, which situated in the Eastern Mediterranean region, with the coastal line of $8,333 \mathrm{~km}$ and $177,714 \mathrm{~km}$ of rivers, and also the marine and inland water sources cover approximately 26 million hectares.

The coastline of Turkey has several small and large estuaries, bays and gulfs that are well protected from storms, currents and winds. The Black, Marmara, Aegean and Mediterranean Seas surrounding Turkey are nontidal and their salinity, dissolved oxygen and temperature properties are influenced by seasonal, morphological and hydrological conditions. The climate, water resources and topography along the coast create favorable aquaculture sites [1].

Aquaculture activities were began with the establishment of first trout farm in 1960s in Turkey. The share of aquaculture has rapidly increased since then. From this point of view, the total production reached
276,502 tonnes in 2017, with freshwater aquaculture production reaching 104,010 tonnes, while marine aquaculture produced 172,492 tonnes. Turkey is ranked as 7th among EU countries when considering production amount. On the other hand, in terms of per capita consumption, which is about $8-10 \mathrm{~kg}$, Turkey is one of the countries with the lowest fish meat consumption $[2,3]$.

One of the typical characteristics of aquaculture sector in Turkey is mostly based on the intensive production of carnivorous fish species such as rainbow trout (Oncorhynchus mykiss), European sea bass (Dicentrarchus labrax) and the gilthead sea bream (Sparus aurata) [4].

\section{Inland Aquaculture}

Although the aquaculture activities begain in inland waters, its potential is not used at its best in spite of procurement of fish fry for inland aquaculture is relatively easier than sea culture. In spite of marine aquaculture production mostly depends on cage farming, freshwater 


\section{International Journal of Oceanography \& Aquaculture}

production is carried out mostly in land-based units, cages set in lakes and hydro-electric or irrigation dams.

The main freshwater species is trout comprising almost all of the total freshwater production. Rainbow trout culture has become dominant in inland waters, whereas carp culture are decreased. In addition, water quality of the dams and artificial lakes are suitable for the culture of some freshwater species such as tilapia (Oreochromis spp.), pike (Esox lucius), European catfish (Siluris glanis) and eel (Anguilla anguilla). Also, the salmonid species such as trout and Atlantic salmon (Salmo salar) are farmed in the brackish waters of the northern coast of the Black sea when the water temperature is low.

\section{Marine Aquaculture}

Marine aquaculture began with the farming of the fries collected from the sea in cages until they reached the market size in 1980s. Following establishment of the hatcheries for the farming of the fries from sea and reaching of them to the enough capacity to meet the demand of facilities, collection of fries from the sea was forbidden completely. The main marine species are sea bass and sea bream with the total production of 161,061 tonnes, which covers $93 \%$ of the total marine aquaculture production. Marine culture of trout and salmon began in the late 1980s. Shrimp farms in the Mediterranean Sea, established in the mid 1990s, encountered many critical problems that still need to be solved.

\section{Aquaculture in Lagoons}

Although there are a lot of lagoons, most of them unusable due to pollution, siltation etc. About 900 tons/year fish is cultivated from these lagoons annually. Other than some expectations, fish production of these lagoons seems to be reducing that mean efficiency is less than $25 \mathrm{~kg} / \mathrm{ha}$ [2].

\section{Future Perspective}

Species such as tilapia (Oreochromis spp.), sturgeon (Acipenser baeri, A. gueldenstaedtii), turbot (Scopthalmus maximus), red porgy (Pagrus pagrus), bluefin tuna (Thunnus thynnus) and common dentex (Dentex dentex) are being cultured on a research level in universities and by the private sector.

Also other Mediterranean fish species such as common sea bream (Pagrus pagrus), sheep head sea bream (Puntazzo puntazzo), common dentex (Dentex dentex), meagre (Argyrosomus regius), brown meagre (Sciaena umbra), white grouper (Epinephelus aeneus), shi drum (Umbrina cirrosa), white sea bream (Diplodus sargus), red-banded sea bream (Pagrus auriga), bluefin tuna (Thunnus thynnus), mussel species (Mytilus spp., Perna spp.) and shrimp are also grown as alternative species.

In addition, the most promising species for the aquaculture are grouper (Epinephelus guaza, E. aeneus), yellow tail (Seriola dumerillii), shi drum (Umbrina sirrosa), crayfish (Astacus leptodactylus), mullet (Mugil cephalus), bluefish (Pomatomus saltator) and European lobster (Homarus gammarus) [1].

\section{References}

1. Memis D, Demir N, Eroldogan OT, Kucuk S (2002) Aquaculture in Turkey. The Israeli J Aquacult 54 (1): 34-40.

2. Anonymous (2013) Aquaculture and Policies in Turkey. Turkey Seafood Company Guide-Aquaculture Life of Turkey, pp: 38-51.

3. Anonymous (2017) Overview of the Turkish fisheries and aquaculture sector.

4. Akbulut B (2004) Aquaculture in Turkey. SUMAE Yunus Research Bulletin 4: 4-6. 